Article

\title{
From Clusters to Smart Specialization: Tourism in Institution-Sensitive Regional Development Policies
}

\author{
Maximilian Benner \\ Institute of Geography, Heidelberg University, Heidelberg 69120, Germany; benner@uni-heidelberg.de \\ Academic Editor: Juan Ignacio Pulido Fernández \\ Received: 28 February 2017; Accepted: 12 July 2017; Published: 17 July 2017
}

\begin{abstract}
In the European Union and its neighborhood, regional development has increasingly come to focus on agglomerations during the last three decades. Notably, during the 1990s and early 2000s, clustering was the major policy focus in regional development. Currently, the concept of smart specialization is applied all over the European Union and is attracting interest in the EU's neighborhood. The tourism sector particularly tends to agglomerate regionally and even locally. While there is a large body of literature describing tourism clusters and while tourism features as a priority sector in many regional development strategies such as smart specialization strategies, there is a research gap on policy approaches applying agglomeration-oriented policy concepts to tourism destinations in an institution-sensitive way. This article argues that both cluster policy and smart specialization can be of considerable value for institution-sensitive tourism development, either when adapted to the specificities of the tourism sector or when integrating tourism development into wider, cross-sectoral strategies of regional development. Such a policy can be a valuable tool for local and regional development, provided that policies are designed in an institution-sensitive manner and respond to the particular institutional context prevailing in a tourist destination. The article illustrates some preliminary thoughts for institution-sensitive tourism development through cluster policy and smart specialization in Cyprus, Israel, and Tunisia.
\end{abstract}

Keywords: tourism; tourism development; clusters; smart specialization; institutions; Cyprus; Israel; Tunisia

JEL Classification: L83; R11; R58; Z32; Z38

\section{Introduction}

Tourism is a highly agglomerated industry. Most visibly, traditional sun, sand and beach package tourism typically clusters in sharply delimited local zones. These tourism zones can be observed, for example, in well-known Mediterranean tourist destinations such as Antalya, Turkey, Ayia Napa, Cyprus, Sousse/Monastir, Tunisia, or Palma de Mallorca, Spain. Even outside these sun, sand and beach mass tourist destinations, tourism clusters in attractive cities and around important destinations including artificially made ones such as theme parks (Benner 2013, p. 3).

The reasons for agglomeration in the tourism sector are straightforward and can be found primarily in the availability of tourism-related assets (such as beaches or other attractions). In this regard, the locational pattern of tourism exhibits some similarity to that of industries extracting natural resources (such as oil production or mining) but less with clustering in other manufacturing or service industries (such as automotive industries or information and communication technologies). Indeed, tourism agglomerations have attracted considerable empirical attention. Research to develop tourism agglomerations on the basis of agglomeration theories exists but is less widespread. When it comes to building on the theoretical insights of agglomeration theories and applying them in an evidence-based 
and institution-sensitive manner to tourist destinations, there is a research gap. Simply copying "traditional" agglomeration-focused policy approaches such as cluster policy to tourist destinations will not suffice because of the peculiar institutional characteristics of the tourism industry. For the same reasons, how to develop the tourism sector will call for special attention within the framework of smart specialization. This article attempts to bridge the research gap mentioned by proposing ways to adapt agglomeration-focused policy approaches in an institution-sensitive manner that allows for considering the institutional specificities of tourism sector as such and of each specific tourist destination.

Indeed, one of the major theoretical strengths of cluster policy and smart specialization is that-at least on a conceptual level-these approaches facilitate the elaboration of regional or local development strategies that are sensitive and adapted to the idiosyncratic institutional context of particular locations. Still, such an institutional fine-tuning is not always done in practice. As the effectiveness of regional and local development critically depends on institutions (Glückler and Lenz 2016), failure to take institutional specificities into account may presumably explain the failure of quite a few regional or tourism development strategies.

To come up with some suggestions on how to adapt policy-related conclusions from the cluster and smart specialization discourses to the specificities of tourist destinations, this article first presents an overview on the state of research dealing with tourism agglomerations. Then, the article outlines the major characteristics of agglomeration-focused concepts in regional development and relates them to the specificities of the tourism sector. In so doing, the article sketches institution-sensitive adaptations of agglomeration policies such as cluster development and smart specialization for the tourism sector, and outlines ways to integrate tourism into wider strategies of regional development focusing on agglomeration. To illustrate possibilities for applying agglomeration-focused concepts of regional development to tourist destinations, the article presents some stylized facts and preliminary thoughts for Mediterranean destinations in Cyprus (Limassol), Israel (Haifa), and Tunisia (Sousse/Monastir). The article concludes by relating agglomeration policies to wider policy goals to promote the diffusion of inclusive growth and employment effects emanating from tourism to peripheral regions, thus situating the subject examined here within the larger context of actual policy challenges in economic development.

\section{Agglomeration and Tourism in Research: Where Do We Stand?}

In economic geography, three dimensions for research have been proposed: Theory, empirics, and policy (Schätzl 1994; Schätzl 2000; Schätzl 2003). These three dimensions are well suited to summarize the state of research on the role of agglomeration in the tourism sector as follows:

- Theory: There is a large body on theoretical work on clusters and similar phenomena such as industrial districts including notably Porter's (Porter 1990; Porter 1998a; Porter 1998b) seminal work but also different or newer approaches (e.g., Dorfman 1983; Enright 2003; Krugman 1991; Piore and Sabel 1984; Saxenian 1994; Scott 1988a; Scott 1988b; Storper and Walker 1989; Wolfe and Gertler 2004). These theoretical works typically develop theories explaining the evolution, the life cycle, or the mechanisms behind the observable phenomenon of agglomeration in manufacturing or service industries in general (Benner 2012a; Benner 2012b). On a conceptual level, these works tend not to be sector-specific but often use sectoral and regional case studies as examples. Mostly, these case studies focus on manufacturing industries or related service industries, notably design-intensive small-scale manufacturing and artisan sectors in Italy's industrial districts (Piore and Sabel 1984) or information and communication technology manufacturing and services in Massachusetts and California (Saxenian 1994; Scott 1988a; Scott 1988b; Storper and Walker 1989). On a theoretical level, tourism usually does not feature as a case for theory design, although it is sometimes mentioned as an example for clustering (Porter 1990, pp. 254-56). Some works use tourism as an example to underline more general points, as does Porter on the aspect of complementarities when he mentions a salient specificity of tourism: 
"In tourism ( ... ), the visitor's experience is affected not only by the appeal and quality of the attraction (e.g., beach, historical site) but also by the quality of the hotels, restaurants, souvenirs, airport facilities, and transportation, making the different parts of the cluster mutually dependent" (Porter 2000, p. 22). Apart from this part of the literature, there is a large body of theoretical literature on tourism as such (e.g., Berg 2010; Steinecke 2011), which, however, rarely deals with theoretical considerations or conceptual thoughts on the fact that the tourism sector agglomerates.

- Empirics: When it comes to empirically observing and describing tourist destinations as clusters, many case studies can be found in the literature including, for instance, wine tourism in California (Porter 1998a; Porter 1998b). It is worth noting that tourism clustering remains very much in Porter's focus. This is evident from the fact that his institute at Harvard Business School has over recent years published a number of student case studies on tourism clusters covering destinations such as Lisbon, Jerusalem, Bali, Monaco, Andalusia, Dubai and Baja California Sur as well as larger countries such as Kenya, Nepal, Tunisia, the Dominican Republic, Italy, Peru, Jordan, Morocco, or Tanzania (Harvard Business School 2017). ${ }^{1}$ Other studies examine tourism clusters in view of the relevance of embeddedness and trust within them (Partalidou and Koutsou 2012) or stress the relationship between cluster and tourism policy (Steenbruggen 2016). In terms of quantitative empirics, there is evidence of the incidence of agglomeration-driven externalities in Spanish tourism clusters (Segarra-Oña et al. 2012), confirming that clustering is indeed a relevant driver of economic development in the tourism sector. Apart from the cluster literature defined in a narrow sense, due to the high prevalence of clustering in the tourism sector, a large number of local or regional case studies in tourism studies can be classified as case studies of tourism clusters (e.g., Bertan et al. 2013; Kassianidis 2013; Mavragani and Lymperopoulos 2013), although they often focus on particular aspects of tourism demand or supply and thus less on the fact of agglomeration, its reasons and consequences.

- Policy: During the heyday of the cluster wave in the late 1990s and early 2000s, practitioners and policymakers moved ahead of literature, thus opening a considerable gap between practical approaches of cluster promotion and (usually much more careful) theoretical considerations of how clusters really can (or cannot) be supported by policy (Kiese 2008). Consequently, theory-informed and evidence-based concepts of cluster policy are rare and considerably younger than many cluster promotion schemes that have been tested in reality (e.g., Benner 2012a; Benner 2012b). There are some examples (Benner 2013; Hjalager 2000; Kachniewska 2013) of attempts to specify these approaches of evidence-based agglomeration-oriented policy approaches to tourism. In particular, Kachniewska (Kachniewska 2013) characterizes the approach of tourism clusters in comparison to regional or local tourism organizations in the case of Poland. Apart from these examples specific for tourism clustering, existing studies often focus on specific horizontal aspects of cluster policy such as the operational management of cluster initiatives or networks (e.g., Kiehlmann 2014). Literature developing approaches and methods or smart specialization (Benner 2014b; Benner 2017a; Foray et al. 2009; Foray et al. 2012) is inherently policy-oriented but has a generic character and thus does not deal with particular sectors or industries such as tourism. Yet, when analyzing existing smart specialization strategies, it is evident that many regions do include tourism in their portfolio or prioritized sectors and have an intention to promote their local or regional tourism industry under the umbrella of their smart specialization efforts

1 The imprecise definition of the cluster concept in terms of spatial scales is evident throughout Porter's work and one of the major aspects of critique against his work (Martin and Sunley 2003). It is questionable whether a whole country covering larger area can qualify as an agglomeration of an industry such as tourism. Most likely, the tourism industry will be concentrated in a number of clearly delimited local or regional-scale destinations in some parts of the country. For example, Tunisia as a country certainly does not qualify as a tourism cluster but rather includes local tourism clusters such as Hammamet, Sousse/Monastir, or Djerba. 
(Ortega-Argilés 2012). On a different note, generic literature on tourism policy (e.g., Berg 2010; Hazboun 2008) does implicitly include policies using agglomeration as a lever for tourism development but usually does not explicitly focus on this particular aspect. An aspect that is rarely treated in works on tourism policy in a local or regional perspective is the need to develop institution-sensitive policies (Glückler and Lenz 2016), that is, policies adapted to the institutional specificities of the tourism sector as such and those of the destination at hand. In turn, literature on the role of institutions in regional development (e.g., Bathelt and Glückler 2012; Glückler and Lenz 2016) does exist but does not specifically focus on tourism and its specificities.

Considering these findings, it becomes apparent that there is a research gap when it comes to the elaboration of policy approaches applying agglomeration-oriented and institution-sensitive policy concepts to tourist destinations in an institution-sensitive manner and based on the existing literature on cluster policy, smart specialization, and institutions in regional development. In an attempt to propose ways to close this research gap, the following section discusses the role of agglomeration in tourism based on the literature introduced above, and discusses institutional aspects in tourist destinations to be taken into account when designing agglomeration-oriented policy approaches to tourism development.

\section{Towards Agglomeration-Oriented Tourism Development}

When looking for drivers of regional development, the classical taxonomy of agglomeration economies comes to mind. While urbanization economies represent the dynamic effects of diversity in cities and the role of cross-sectoral creativity and serendipity, localization economies point to opportunities of knowledge spillovers and learning connected to density in the same or closely related activities (e.g., in clusters) (Bathelt and Glückler 2012, pp. 153-54). For tourism, both types of agglomeration economies can be relevant: ${ }^{2}$ Urbanization economies are what typically drive tourism in cities because tourists seek the cultural and commercial diversity available in (larger) cities. In contrast, the kind of sun/sand/beach mass tourism that can be found all over the Mediterranean is based more on localization economies: Tourism service-providers such as hotels, restaurants, tour guides, or entertainment venues locate there because of each other's co-location (and to some degree, because of pre-existing assets such as beaches). ${ }^{3}$

While city tourism based on urbanization economies requires assets that cannot be constructed by and for the tourism sector alone, localization economies in sun/sand/beach mass tourist destinations can arguably be more easily shaped by targeted interventions of tourism policy. In either case, however, the role of agglomeration for tourism development is evident. If this is so, one might argue, approaches of regional development that focus on agglomeration can be highly relevant for tourism development.

Considering the high relevance of agglomeration economies in the tourism sector, there is a strong case for refining agglomeration-oriented approaches of regional development such as cluster policy and smart specialization in view of their application to tourist destinations, and to do so in an institution-sensitive way. To do so, the role of institutions in regional development is introduced in the next sub-section. Then, some specificities of tourism are highlighted. Finally, this section discusses how these specificities can be taken into account in cluster policy and smart specialization, and as a component of wider, cross-sectoral regional development strategies in an institution-sensitive manner.

2 Tourism does not have to be based on density, though. Some kinds of tourism prosper on their distance from urban life or from popular mass tourist destinations. In these cases which include, for instance, luxury resorts in isolated desert locations, peripheral destinations offer assets not based on agglomeration economies. These kinds of destinations are not the focus of this article.

3 In practice, there will be some degree of localization economies within the tourism sector in larger cities, while some degree of quasi-urban diversity may be present in sun/sand/beach mass tourist destinations, leading to some urbanization economies. Thus, in reality the delimitations between the effects of both categories are not so clear-cut or unambiguous. 


\subsection{Institutions in Regional Development}

Institutions have become one of the major objects of analysis in economic geography in recent decades (Bathelt and Glückler 2012; Glückler and Lenz 2016). Institutions can be understood "as legitimate mutual expectations enacted in stable patterns of social interactions" (Glückler and Lenz 2016, p. 260). As such, they interact with prescriptive rules such as laws and explicit policies and condition their effectiveness (Glückler and Lenz 2016). Consequently, the development and implementation of regional policies has to be sensitive to the idiosyncratic institutional context of regional or local economies. In particular, regional policy needs an understanding "on which incentives individual behavior is based: is it guided by official rules, or are people following behavioral expectations that deviate from official rules?" (Glückler and Lenz 2016, p. 272).

While regional policies such as cluster initiatives have been subject to institutional analyses (e.g., Lehmann and Benner 2015), institutional analysis of tourism clusters is-to the author's knowledge-still an underdeveloped field of research. Considering the specificities of tourism (see Section 3) and the resulting need for collective action between a considerable number of agents within tourist destinations and beyond, and in view of the high complexity of tourism landscapes in many countries including, for example, private tourism enterprises, various levels of government, tourism associations, government-owned enterprises, semi-governmental or non-governmental organizations, and the multitude of more or less formalized interactions between these organizations (Benner 2013; Hjalager 2000; Kachniewska 2013), this lack of institutional analysis is surprising.

While this article cannot go into the details of institutional analysis of the tourism sector, it calls for more sensitivity for the functioning and evolution of institutions in tourism development. Later in this article, some ideas will be presented on how to ensure institutional sensitivity when applying the notions of cluster promotion and smart specialization to the tourism sector. In general, doing so requires an understanding of the interplay of rules or policies on the one hand, and institutions on the other. Glückler and Lenz (Glückler and Lenz 2016) propose a taxonomy of interactions between rules and institutions that enables a clearer understanding of the possibilities and limits of regional policies in a particular institutional context. This taxonomy includes the following relevant cases (Glückler and Lenz 2016, pp. 264-70):

- Rule-reinforcing institutions underscore the effectiveness of rules and policies, possibly rendering regional policies more efficient. Similarly, but in the opposite direction, institution-reinforcing rules ensure synchronization between policy and institutional context and provide good chances for policy effectiveness. ${ }^{4}$

- Rule-substituting institutions and rule-circumventing institutions might involve a strong degree of micro-level agency (Benner 2014b; Benner 2017a) including institutional innovation and entrepreneurship. These types of interaction severely limit the effectiveness of explicit policy or rule-making, but they might equally represent a reaction by micro-level agents to political sclerosis and inertia.

- Institution-circumventing rules may be necessary for policy to react to harmful institutions, but efforts to enforce them will be needed. This case is especially interesting for tourist destinations, especially for those in need of competitive upgrading. For example, lacking competitiveness of enterprises or trading-down processes of neighborhoods or locations are situations where policies creating institution-circumventing rules may be beneficial. Cluster

4 These cases do not necessarily need to be beneficial for the aggregate economy or even for the region or sector in question. Rules and institutions can be consistent but still lead to inefficient results, for example in a lock-in situation (Grabher 1993). If, however, policy goals embodied in rules and institutions are directed towards efficiency-enhancing ends, consistency between rules and institutions arguably suggests higher degrees of effectiveness in reaching these policy goals (such as growth and employment creation). 
initiatives or schemes such as business improvement districts can provide a forum for anchoring such new rules, and for facilitating the emergence of consistent institutions.

- Rule-competing institutions and institution-competing rules are cases in which explicit policies face low chances of success, at least in the long term. Then, it might be wise to look for alternative mechanisms to shape institutional change such as institution-circumventing rules.

This taxonomy of interactions between prescriptive rules (instituted, upheld, modified and eliminated by explicit policies) and institutions offers lessons for the design and implementation of regional or local development strategies and more specifically tourism development strategies. Before introducing institutional aspects in agglomeration-oriented approaches to tourism development, the next sub-section sketches specificities of the tourism industry and their relevance for tourism agglomerations.

\subsection{Tourism and Agglomeration}

Tourism differs from manufacturing industries or from other service industries in a number of important aspects. In particular, tourism's essential product (the destination) is a public good. A destination's attractiveness to tourists is shaped by actions and investments undertaken by a multitude of agents-private enterprises, local or regional government, national government, real estate owners, inhabitants, and many others, featuring a range of complementarities between them (Kachniewska 2013, p. 39; Porter 1998b, p. 81; Porter 2000, p. 22). Basically, these features of the tourism product mean that "tourists tend to base their judgments on the satisfaction with a vacation experience on all the components of a complex tourism system" (Kachniewska 2013, p. 39). Maintaining or upgrading a destination's attractiveness and competitiveness requires cooperation between public and private agents (Kachniewska 2013, p. 40) or even a form of collective action and poses coordination problems typical to public goods, including notably the danger of free riding. Consequently, a strong coordination role of public policy is required. Local or regional government thus performs three roles: Firstly, local or regional (as well as national) government has to set the framework conditions for economic action-as it does for all industries. Secondly, local and regional government (and sometimes national government, too) may become involved in co-production of the tourism product, for example by providing fee-based services and maintaining tourism-relevant economic, transport or cultural amenities such as airports, railroads, conference centers, museums, concert halls, spas, or public swimming pools. Thirdly, local and regional government has to play a leading role in coordinating the joint public-private "production" of the destination, notably by facilitating collective processes of upgrading (Benner 2013).

Local or regional government's facilitating role (which may be devolved to specific agents such as tourism development agencies) can employ a host of "soft" measures such as initiating dialogue, providing market intelligence, or attempting to convince private agents to invest in upgrading the destination's competitiveness. When it comes to collective or public action, which requires funding but benefits the tourism sector as a whole (according to the public-good property of non-excludability) such as maintaining museums, investing in a more attractive urban space, or running a marketing campaign for the destination as such, there is a high danger of free-riding by private enterprises (Benner 2013, p. 9).

Such a free-rider problem may go so far as to even render infeasible actions that could significantly upgrade the destination's attractiveness and competitiveness as a whole and thus benefit all parts of the tourism sector, implying a "prisoner's dilemma" known from game theory. In such a situation, it might be a legitimate goal of tourism policy to establish institution-circumventing rules, for example when a destination is subject to trading-down processes and/or suffers from a bad reputation, or when market developments force a destination to renew itself altogether. As was argued in Section 3.1, institution-circumventing rules need enforcement, suggesting some combination of "hard" and "soft" policy instruments as will be introduced in the next section. 
It needs to be emphasized, however, that the coordinating and facilitating role local or regional government has to play in tourism development does not call for top-down dirigisme. The second and third roles of local and regional government in tourism development, that is, its role in co-production through public services or amenities and its role in coordination and facilitation require a market-oriented outlook of policymakers because-arguably much different from regular economic policy where governments do not directly face market competition-tourism policy seeks to improve a destination's competitiveness on the market. What is needed, then, is entrepreneurial thinking by policymakers. Considering the specific rationales of politics and administration (Kiese 2008), there is reason to be skeptical about whether public policy is capable of making effective and quick entrepreneurial decisions. This skepticism calls for joint public-private steering structures and processes to ensure market alignment. Cluster policy and smart specialization provide a set of instruments for how to establish public-private steering and dialogue platforms. Yet, openness to the ideas of "outsiders" and "newcomers" (Benner 2014b; Benner 2017a; Benner et al. 2016) will have to be ensured to prevent a dangerous lock-in situation (Grabher 1993).

\subsection{Tourism Cluster Policy}

Clusters as a focus of regional policy became fashionable during the first half of the 1990s, fuelled primarily by the reception of Porter's (Porter 1990) seminal work amongst policymakers, first in industrialized and later in emerging and developing countries. Despite a lot of theoretical critique about the cluster concept's fuzziness (Martin and Sunley 2003), practitioners and policymakers all over the world have been quick to apply the cluster focus in a wide range of economic development strategies on local, regional, national, and even supranational levels (Benner 2012a; Benner 2012b).

Notwithstanding the wide variety of definitions available in the literature (Benner 2012c, p. 3-4), clusters can be seen as spatial agglomerations along a value chain that necessarily include enterprises (on the same stage or on different stages of the value chain) and that may optionally include related agents (e.g., education or research entities, associations, chambers of commerce), and in which some kinds of competitive, cooperative, innovative, or social capital-related interactions occur within a specific localized institutional context (Benner 2012a, pp. 7-11).

While it is possible to apply cluster policy in peripheral regions-notably in tourism, agriculture, or crafts-more typical cluster policies such as those directed towards information and communication technologies, automotive industries, or other "high-tech" sectors often tend to benefit urban core regions more, thus intensifying growth differentials between dynamic and lagging regions (Benner 2017b, pp. 51-57).

When it comes to the dynamics within clusters, mechanisms of agglomeration, which may drive interactions and spillovers, can be identified, as can policy interventions to shape these interactions. For example, if and when needed, cluster policy might focus on labor market-related interventions such as job fairs or internship schemes. Fostering cooperation among cluster enterprises is another (and popular) field of action for cluster policy, but fostering competition between them is yet another field not to be forgotten. While the latter goal may encounter skepticism from cluster companies and may be more difficult to pursue than incentivizing cooperation, upgrading cluster companies' competitive strength (which often is an important objective in tourism development) will typically require some kind of competitive pressure (Benner 2012a; Benner 2012b; Benner 2012c).

Responding to some questions asked in the research agenda on tourism clusters or districts proposed by Hjalager (Hjalager 2000, pp. 11-13), a specific method of cluster policy for tourism agglomerations might include agents such as private tourism enterprises, tourism associations on various levels (Kachniewska 2013), government agents such as local and regional government and government-owned enterprises, education and training entities (e.g., vocational schools for hospitality occupations), and cluster management (Benner 2013). In practice, cluster policy typically focuses on networking and collaboration (Benner 2012a; Benner 2012b), which has become the centerpiece of the work of organized cluster initiatives. In the case of tourism clusters, networking and collaboration 
between cluster members might be managed by critical facilitating agents such as tourism development agencies or tourism associations. In some cases, existing tourism associations will already function as organized networks and thus as equivalents to the organized cluster initiatives, which are often set up under the umbrella of cluster policies in other industries. This is why Kachniewska (Kachniewska 2013) sees chances for transformation regional or local tourism organizations constituted as associations into the backbone of tourism clusters, or what is called here tourism cluster initiatives. Such a forum may provide opportunities for policy dialogue between policymakers and enterprises, possibly facilitating the emergence of rule-reinforcing institutions or institution-reinforcing rules. In cases when rules and policies are subject to political sclerosis or inertia, such a facilitating and networking forum may eventually act as catalyst for the emergence of beneficial rule-substituting institutions through micro-level agency.

In cases in which a destination faces pressure to upgrade its competitiveness, requiring a combination of public and private investments, the improvement of its reputation, and/or entry into new markets or niches, cluster policy can provide a framework to organize a collective framework approach. Such an effort will often require institution-circumventing rules, as well as corresponding and effective enforcement mechanisms. This is a case in which the typically "soft" instruments of cluster policy may be complemented by "hard" instruments to prevent the free-riding problem outlined in the preceding section. Following the model of business improvement districts known from urban planning and aiming at the interception and reversal of trading-down processes under a lack of private investment, designating a tourist destination or part of it as a tourism improvement district can serve as an example for such a "hard" enforcement mechanism for institution-circumventing rules. In such a model, tourism enterprises located in the designated tourism improvement district are required to pay a special tax into a fund. This fund then undertakes investments, which improve the destination's overall attractiveness and competitiveness (Assli 2009).

After two decades of debate on clusters in the literature, it is obvious that institutions matter. Numerous voices in the literature warned early on that there could not be a single, "one size fits all" recipe for promoting clusters anywhere, in any sector, in any context, or at any time: As Enright (Enright 2000) noted already in 2000, because cluster policy is meant precisely to promote local or regional specifics, it needs to be adapted to a region's or locality's idiosyncratic context (Enright 2000, p. 327). Building mainly on agglomeration economies and thus being relevant primarily for highly agglomerated destinations such as sun/sand/beach mass tourism zones (or small-scale tourism clusters in cities), cluster policy can promote mechanisms of clustering including the following ones by taking into account the kind of institutions prevailing in a specific tourist destination (Benner 2012a; Benner 2012b; Benner 2012c; Benner 2013):

- Labor-market mechanisms such as mobility of workers between enterprises or mobility of graduates from education and training entities towards enterprises, or student internships can be promoted by schemes such as job fairs, matching initiatives, internship placement arrangements, internship or thesis scholarships, or social media campaigns. Considering that tourism is a labor-intensive industry and that quality in tourism is affected to a large degree by the skills and training of workers, the availability of a qualified workforce is a critical factor of a destination's attractiveness and competitiveness.

- Cooperative mechanisms such as vertical or horizontal collaboration between enterprises (e.g., in marketing the destination as such), public-private dialogue, or joint lobbying towards policymakers can be promoted through targeted investments (such as grants) for collaborative actions or dialogue-inducing and trust-building measures such as conferences and roundtables. At the intersection between labor-market mechanisms and cooperative mechanisms, quality can considerably be improved through joint training programs between enterprises and education or training entities. Joint initiatives to attract qualified workers from other locations are another example for cooperative schemes of tourism cluster policy. 
- Knowledge spillovers such as "cafeteria effects" may be somewhat less important in the tourism sector than in "high-tech" industries but will still occur to some degree. Promoting them with policy tools is difficult, however, and boils down to cooperation-inducing and trust-building instruments as were described above.

- Entrepreneurship in a tourism cluster can be promoted, for example, through thematic business planning contests or improved access to capital for start-ups with tourism-related business models. Setting up coaching and mentoring schemes, for example, by matching young entrepreneurs with retired tourism executives who act as mentors, can further improve new business formation and growth in tourism and thus contribute to upgrading the destination's competitiveness by facilitating the emergence of new trajectories through entrepreneurship and (service) innovation (Benner 2014b; Benner 2017a), and even to overcoming a lock-in situation the destination might eventually face in the absence of entrepreneurialism (Grabher 1993).

- Competition between incumbent enterprises is difficult to affect, but in addition to promoting entrepreneurship as was described above, some limited policy interventions are feasible. Policy interventions designed to enhance competition related to quality among incumbent tourism service providers include, for instance, quality contests or rating schemes. ${ }^{5}$ In combination with policy efforts designed to establish institution-circumventing rules such as tourism improvement districts, interventions aiming towards increasing competition and differentiation among enterprises could contribute considerably to upgrading a destination's competitiveness and attractiveness.

Instruments of cluster policy such as those introduced here can significantly contribute to the development and upgrading of tourism clusters. Yet, the effect of these instruments tends to be limited in terms of facilitating tourism development in fields of convergence or complementarity with other sectors or industries. While instruments of cluster policy designed to promote entrepreneurship may stand some chance of shaping trajectories of convergence or complementarity with other industries (for example, information and communication technology applications for tourists or tourism service providers, or tourism safety and security solutions), such an outcome is either uncertain at the outset or requires a pre-identification of fields of convergence or complementarity. Identifying these fields may be difficult to achieve under the sectorally constrained framework of cluster policy, calling for broader notions of regional development. Thus, to develop tourism in a more systemic way as a driver of regional development, in interaction with other sectors and industries, and rooted in localized assets and capabilities drawn from the regional knowledge base, a wider view towards regional specialization is necessary. Smart specialization offers such a wider view, as well as a methodology to develop and implement broader regional development strategies. In tourist destinations, tourism development will logically be a major thrust of such a more generic regional development strategy, and tourism cluster policy along the lines presented here can form a major part of the strategy and its implementation. The next section introduces some thoughts of how to combine tourism development with other domains of regional development under the umbrella of a smart specialization process.

5 The high importance and visibility internet rating portals such as TripAdvisor have achieved for competition among companies in the tourism sector is evident, for instance, in the fact that many hotels publicly display TripAdvisor's "Certificate of Excellence" (TripAdvisor, L.L.C. 2016). Similar quality-focused and competition-enhancing rating and award mechanisms are possible on the local and regional level including, for example, shop-window competitions for retailers. Where broadly accepted rating and award mechanisms such as online hotel or restaurant rating portals exist, tourism policy might wish to align its incentives with these schemes, e.g., by making an improvement of internet ratings or an increase of TripAdvisor "Certificates of Excellence" awards to the destination's hotels, restaurants and attractions an explicit goal of tourism policy. Such an alignment of public and private incentives can take the form of an institution-reinforcing rule. Systematically monitoring internet ratings of a destination's hotels, restaurants and attractions can be an important task of tourism cluster management and serve as a monitoring and evaluation tool for the destination's competitiveness, as well as help identify further measures of tourism cluster policy to enhance quality and competition. 


\subsection{Tourism in Smart Specialization Strategies}

Regions all over the European Union (and beyond) have developed their own regional research and innovation strategies for smart specialization (RIS3), fuelled primarily by the European Commission, who has made the existence of a RIS3 an "ex-ante conditionality" for access to certain lines of funding by EU structural funds for regional development for the period covering 2014 to 2020 (Foray et al. 2012). Perhaps not surprisingly, RIS3 have become the umbrella for many regions' efforts to promote clusters.

While cluster policy focuses on localized parts of a value chain and thus tends to take a (horizontally or vertically) sectoral perspective, the concept of smart specialization looks towards deeper specializations in a region's economic structure. Such specializations refer to economic activities rooted in a region's knowledge base and can be sectoral but also cross-sectoral. Clusters can thus form a part of regional specialization but so can cross-cutting capabilities or assets (Benner 2017a; Benner et al. 2016).

Furthermore, while clusters are inherently related to specialization and will often form part of smart specialization strategies (Benner 2017a), the notion of smart specialization focuses on interrelationships and complementarities between industries and sectors or what Asheim et al. call "diversified specialization" (Asheim et al. 2016). This means basically that as part of the smart specialization process, "regions should diversify their economies primarily based on existing strengths and capabilities by moving into related or unrelated sectors" (Asheim et al. 2016, p. 4).

Smart specialization offers a methodology for a participatory process to involve stakeholders in a regional economy in the prioritization of political interventions to promote specializations and to allocate resources and distribute tasks accordingly. Rather than setting priorities in a hierarchical top-down process, smart specialization calls for an "entrepreneurial process of discovery" (Foray et al. 2009; Foray et al. 2012) involving enterprises, academia, policymakers, and other stakeholders. Just how to organize this process is an open question because of the necessity to keep the prioritization process open to the effects of micro-level dynamics and to the ideas of "outsiders" or "newcomers" such as students, young graduates, or (immigrant) entrepreneurs (Benner 2014b; Benner 2017a; Benner et al. 2016).

Tourism can be one of the pillars of a smart specialization strategy of regions with touristic assets. As such, the tourism sector would be prioritized in the "entrepreneurial process of discovery" leading to the formulation of a RIS3 (Foray et al. 2009; Foray et al. 2012) and promoted during the implementation of the strategy and the action plan derived from the strategy and the priorities set in it. The instruments of tourism cluster policy that were introduced in the previous section can well be integrated into such an approach to tourism development. Basically, what the "entrepreneurial process of discovery" means in relation to tourism is facilitating the emergence of a diversified specialization (Asheim et al. 2016), combining tourism activities with other industries or sectors (e.g., e-tourism solutions, wine tourism, culinary tourism) or developing new dimensions of the tourism industry focusing on assets available in the regional knowledge base, and to do so through prioritization and action planning.

At the same time, tourism might draw on more generic capabilities available in a region and rooted in the regional knowledge base. The smart specialization approach focuses its attention on these more generic capabilities and on economic activities emanating from the regional knowledge base, which can be sectoral or cross-cutting (Benner et al. 2016).

As the smart specialization perspective does not focus exclusively on sectoral clustering but takes into account complementarities or convergence between economic activities if rooted in the same or similar assets within the regional knowledge base (Benner 2017a), it is relevant not only for shaping, building or strengthening localization economies in sun/sand/beach mass tourist destinations but also for urbanization economies in larger cities. For example, regional assets in terms of culture, creativity or urbanism can generate positive spillovers for the tourism sector and strengthen urbanization economies in cities, making them more attractive to tourists. 
In appropriate cases, an RIS3 with tourism as one of its pillars might focus on upgrading a tourist destination with the goal of establishing institution-circumventing rules, either within the tourism sector in a narrow sense (as was illustrated in the previous section) or in a broader, cross-cutting perspective. For instance, the establishment of institution-circumventing rules directed at cross-cutting economic activities that include but are not limited to the tourism sector might aim at improving a region's ecological balance or at promoting sustainable consumption and production. Such a thrust would include not only the tourism sector but equally span related areas such as urban planning, environmental policy, cultural and creative industries, manufacturing, and many others.

On a procedural level, the "entrepreneurial process of discovery" inherent to the smart specialization approach (Foray et al. 2009; Foray et al. 2012) can serve as a method to discover and analyze regionalized or localized institutions. This participative process structures a broad public-private dialogue and can be used to distinguish between rules and institutions, and to examine the interactions and relationships between them (Glückler and Lenz 2016). For example, it would be worthwhile for agents to discuss which institutions are rule-reinforcing (and vice versa) because such a type of interaction provides for consistency and offers good chances for policy effectiveness. The prevalence of rule-substituting institutions and rule-circumventing institutions may suggest ineffective policies and thus call for regulatory reform. Needs for upgrading the competitiveness of sectors may call for institution-circumventing rules and mechanisms to enforce them (such as the establishment of a tourism development district). The existence of rule-competing institutions and institution-competing rules implies a suboptimal pattern of interaction between policy and institutions and may lead agents to look for alternative patterns to shape their region's or locality's institutional context.

While the participatory entrepreneurial process of discovery or, more precisely, collective prioritization and action-planning process, inherent to the smart specialization concept offers an opportunity to develop institution-sensitive regional policies, success in doing so is far from guaranteed. For such an institutional review to function effectively, it is important to ensure openness to the ideas of "outsiders" and "newcomers" such as new entrepreneurs, immigrants (including notably migrant entrepreneurs), graduates, students, and other entrepreneurial structures outside of pre-existing representative structures. The ideas and views of these agents can be highly important to prevent a dangerous lock-in situation (Grabher 1993) that might, in the case of tourism, lead to a destination losing its responsiveness to market trends and therefore to a decline in competitiveness vis-à-vis competing destinations. Further, new ideas and views are important to counter the dominance of vested interests represented by a small number of highly visible and well-connected entrepreneurs which, in the tourism sector, may be overrepresented in the tourism sector's structures such as tourism associations and councils, and whose opinions will thus be influential from the outset and may skew strategy formulation and prioritization processes in their favor (Benner 2014b; Benner 2017a; Benner et al. 2016).

Either as a part of an RIS3 promoting cross-cutting economic activities based in specializations in a region's knowledge base, fields of convergence between existing specializations, or complementarities between clusters or sectors, or as a part of all-encompassing regional development strategies that do not follow the smart specialization perspective and methodology, tourism development can be anchored in cross-sectoral strategies for regions with touristic assets. To this end, the next section discusses the interplay between the tourism sector and other sectors or industries and argues for introducing institution-sensitive policy tools into such a strategy.

\subsection{Anchoring Tourism Development in Cross-Sectoral Strategies}

As was argued in the previous section, tourism development can be integrated into broader regional development strategies, based on the smart specialization perspective and methodology or not. Even in regional development strategies that encompass all sectors and thus do not take the perspective of regional specialization or clustering, tourism development can be regarded in view of 
its interactions and complementarities with other components of the regional economy, allowing for a synergistic view towards regional development.

Tourism provides a wide range of possible complementarities and intersections with other sectors or industries, allowing for regional development driven by the cross-cutting effects and spillovers of tourism into other parts of the regional economy, or vice versa. For example, a regional development strategy (or a more specific RIS3) might embrace the notion of a high quality of life as its guiding vision. Such a "high-road" regional development strategy (Pike et al. 2017, pp. 47-48) could operationalize the guiding idea of improving the quality of life by promoting economic activities, which contribute to a high quality of life, possibly including high-quality, sustainable, and environmentally-friendly forms of tourism, organic agricultural production, and state-of-the-art urbanism. Even short of such a broad vision, developing tourism niches with high quality and high value-added can be suitably combined with objectives of high-quality growth in industries such as food, design, winemaking, or agriculture.

Again, an institution-sensitive perspective towards tourism development (or regional development in general) is worth taking. When it comes to promoting broad developments in the regional economy, which include tourism and its complementarities and interactions with other sectors or industries, it will be necessary to carefully examine the institutional context of the regional economy beforehand. Such an analysis is important to ensure consistency of the regional economic strategy and to discover and discuss possible institutional blockages or contradictions. Furthermore, when it comes to sectoral complementarities or intersections between tourism and other industries (e.g., agri-food industries), the institutional specificities of both industries will need to be taken into account.

\section{Cases for Agglomeration-Oriented Tourism Development in Mediterranean Countries}

Based on the thoughts presented in the preceding section on how to promote tourism development through agglomeration-oriented approaches, this section presents three cases and introduces some preliminary ideas on how to align tourism development with the possible benefits of agglomeration, taking into account the institution-sensitive perspective advocated here (Glückler and Lenz 2016). The following cases from Cyprus, Israel and Tunisia are meant to serve as illustrative examples on how agglomeration-oriented tourism development strategies could look like in view of the specific institutional context in these tourist destinations.

The case studies are based on three research projects on regional development or institutional economics. The first case study is based on a study taking stock of the regional economy in Limassol, Cyprus and developing possible avenues of regional development in the context of the country's current structural reform process (Benner et al. 2017). The second case study is based on a study that examined the regional economy of Haifa, Israel and proposed areas for diversified specialization under the smart specialization concept (Benner et al. 2016). The third study about Sousse/Monastir in Tunisia is based on ongoing work in a research project about institutional features of Arab economies with a focus on Tunisia and related publications on regional development in Tunisia (Benner 2014a; Benner 2017b; Benner; Lehmann and Benner 2015). For the purpose of the present article, the research pursued under these three projects, which concentrated so far on literature reviews, document analyses and desk research, has been screened in view of its implications for tourism. This section thus presents an extract of insights from these three research projects as far as they are relevant for tourism, and on this basis develops further ideas on how to develop institution-sensitive tourism development policies in tourism agglomerations.

It has to be noted that due to the methodological limitations of these case studies, more profound research will be needed to develop more detailed approaches towards agglomeration-oriented tourism development in the countries or regions covered. In particular, in-depth explorative qualitative research on the ground will be necessary to come up with a precise analysis of agglomeration tendencies and the state of the tourism sector in these destinations, and for detailed strategy development towards comprehensive agglomeration-focused tourism development strategies. Therefore, insights drawn 
from the case studies presented here should be regarded as stylized facts that are meant to guide further discourse on the subjects addressed.

\subsection{Benefitting from Urbanization Economies: The Case of Limassol}

Limassol is one of the major economic centers on the island of Cyprus and has in recent years benefited from its role as the country's primary port city. In addition, Limassol and its environment is a major tourist destination in Cyprus, featuring tourist attractions including ancient excavation sites such as Kourion, historical castles such as Kolossi, the Cyprus Wine Museum, and beach resorts. As a city-region with more than 200,000 inhabitants, Limassol enjoys a degree of urban dynamism, which suggests considerable urbanization economies. Festivals such as the Limassol Wine Festival and the Limassol Carnival attract thousands of visitors. The new marina and various architectural landmarks currently being built are shaping the city's face and give the city renewed international attention. Plans for a large casino resort are expected to stimulate further growth in tourism to Limassol, adding to the recent surge in tourist arrivals to Cyprus (Benner et al. 2017).

Promoting tourism development in Limassol along a strategy focusing on tourism-related agglomeration economies could, for instance, involve initiatives which link various sources of the city's and region's attractiveness as a tourist destination. Limassol's location close to the country's wine-growing region south of the Troodos mountains and its related attractions (e.g., the Cyprus Wine Museum and the Limassol Wine Festival) may be combined with efforts to promote culinary tourism which could embrace recent international trends such as food trucks and food tours. The city's role as a major Mediterranean port city suggests opportunities for attracting cruise tourists, possibly in promising premium niches of the cruise industry such as wine cruises. As a large city in an EU member country, Limassol could promote its attractiveness to visitors in medical tourism, thereby lessening its strong exposure to seasonality (Benner et al. 2017).

Basically, then, a tourism development strategy for Limassol based on urbanization economies would promote synergies between the diverse assets the city offers, and link fields such as classical sun/sand/sea package tourism, culinary and wine tourism, medical tourism, cruise tourism, and cultural tourism. Particularly in the latter field, Limassol as a large city has the potential to offer a considerable degree of cultural diversity that can underpin the city's attractiveness as a tourist destination.

Taking an institution-sensitive perspective, it seems as if current tendencies in tourism development in Limassol are well in line with the goals of an agglomeration-oriented tourism development strategy. Investments currently underway such as urban upgrading, the new marina, or the planned casino resort (Benner et al. 2017) suggest that upgrading tendencies in Limassol's tourism sector (or tourism-related sectors) are ongoing. Following the taxonomy proposed by Glückler and Lenz (Glückler and Lenz 2016), an agglomeration-oriented tourism development strategy might support these upgrading tendencies through institution-reinforcing rules, which could involve, for example, policy interventions to market the city's upgraded attractiveness internationally or targeted public investments in complementary attractions such as museums, theaters, or art galleries.

\subsection{Promoting Tourism under Smart Specialization: The Case of Haifa}

The city of Haifa is Israel's third urban center after Tel Aviv and Jerusalem and is historically an important location for manufacturing and logistics, considering its status as a port city. As such, Haifa for a long time did not feature among the country's prime tourist destinations, despite attractions such as the well-known Baha'i gardens, Madatech science museum, or Haifa University's Hecht archeological museum. Recently, the city's profile as a tourist destination has improved, due in part to public investments such as the renewal of the historical German colony quarter or the construction of the International Conference Center. In addition, Haifa is the logical gateway to the north of Israel with its touristic sites in the Galilee such as the religiously important cities of Safed and Tiberias, the 
Sea of Galilee with its Christian sites, historical cities such as Akko, and the wine routes of the Galilee and Carmel regions (Benner et al. 2016).

In an attempt to sketch possible guidelines for a smart specialization strategy for Haifa, Benner, Bieringer et al. (Benner et al. 2016) suggest focusing on links between various assets in Haifa's regional economy, which rests on information and communication technologies, life sciences, the chemical industry, logistics, aerospace, and tourism. It is noteworthy that Haifa is one of Israel's primary locations for science and education with the University of Haifa, the Technion Institute for Technology, and the Rambam medical center, supplying the city and its region with a wide array of skills covering diverse fields of competence. Tourism is one of these fields of competence since the University of Haifa hosts the Israel School of Tourism (Benner et al. 2016).

While not all sectors structuring Haifa's regional economy are suitable for promoting links or complementarities with the tourism industry, some sectors are well compatible with a strategy of supporting promising niches of tourism. In particular, the city's tourism sector could strongly benefit from the strength of the regional economy's life sciences industries. Assets such as the well-known Rambam medical center could serve as a backbone for developing medical tourism. Haifa might strengthen its position in wine tourism and position itself as a gateway to neighboring wine-growing regions such as the Galilee or Zikhron Ya'akov. As a port city, Haifa has the potential to attract a sizeable number of cruise tourists. Lastly, Haifa's reputation for Jewish-Arab coexistence could serve as a theme to develop cultural offers such as the existing "Holiday of Holidays" festival and extend them to other niches in tourism, for example by organizing specifically dedicated art festivals or by promoting culinary tourism around signature "coexistence" culinary products such as hummus or falafel (Benner et al. 2016). ${ }^{6}$

Developing strategic thrusts for tourism development in a smart specialization process arguably calls for a combination of institution-reinforcing rules and institution-circumventing rules according to the taxonomy suggested by Glückler and Lenz (Glückler and Lenz 2016). Considering the city's efforts in upgrading its attractiveness as a tourist destination involving, for instance, the renewal of the historical German colony quarter (a public investment which itself might be regarded as a policy to establish institution-circumventing rules by initiating an upgrading process and improving the prospects for accompanying private investment), supporting the ensuing dynamic in the private tourism sector might render institution-reinforcing rules promising. In fields where sufficient private dynamism may not yet be visible such as developing new initiatives towards cultural or culinary tourism, policies focusing on institution-circumventing rules and resulting public investment (e.g., in new cultural venues or events) might be worth considering. For instance, supporting medical tourism might involve public initiatives to bring together agents from different sectors-public and private healthcare providers, life science enterprises, and tourism companies-to develop a common strategy and to specifically market the destination internationally.

\subsection{Integrating Tourism in a Cross-Sectoral Regional Development Strategy: The Case of Sousse/Monastir}

Tunisia is an interesting case for tourism development. Agglomeration has been a fact of Tunisian tourism since its inception in the 1960s and indeed, it was politically intended. Hazboun (Hazboun 2008, p. 23) sketches the political intention to concentrate tourism in "tourist zones" and the location of the country's three major international airports close to these tourism clusters of Tunis/Hammamet, Sousse/Monastir and Djerba. Another salient fact about tourism in Tunisia is that

6 The strategic thrusts for tourism development in Haifa look similar to those proposed above for Limassol, reflecting the cities' similar structural characteristics. Yet, it is important to note that the strategic perspectives pursued in the two cases is different: While the ideas presented in the case of Limassol were founded on the assumption of urban diversity and possible trajectories emanating from such a diverse urban landscape, the ideas suggested for Haifa are based on existing sectoral strengths in the city's economy. In a different environment, these two different strategic perspectives might lead to significantly different conclusions. In practice, however, both perspectives can be combined into an integrated and more generic regional development strategy. 
with more than 7.8 million international tourist arrivals in 2010, Tunisia used to be one of the major tourist destinations in the Mediterranean. Since then, lower demand due to the post-revolutionary situation and violence against tourists in 2015 has led to a significant contraction in tourist arrivals (World Tourism Organization 2016, p. 11).

On a more fundamental level, however, Tunisia's tourism sector has potential for upgrading its competitiveness. The World Economic Forum (World Economic Forum 2015) ranks Tunisia 87th among 136 countries in tourism competitiveness, significantly behind its main Mediterranean competitors of Spain (1st place), France (2nd), Italy (8th), Portugal (14th), Greece (24th), Croatia (32nd), Malta (36th), Turkey (44th), Cyprus (52nd), Morocco (65th), Montenegro (72nd), and Egypt (74th). The only Mediterranean countries trailing Tunisia are Lebanon (96th), Albania (98th), and Algeria (118th). While safety and security concerns do affect Tunisia's ranking, some fundamental areas of improvement are apparent: For example, Tunisia is ranked 113th internationally on its human resources. While global competitiveness indices based on a mix of quantitative input variables measured on the macro level should be handled with care, the fact that the average spending per international tourist stood at only 257.70 USD compared to 575.10 USD in Morocco, 663.60 USD in Egypt, 674.20 USD in Turkey and 1080.80 USD in Jordan does indeed suggest room for competitive upgrading in the Tunisian tourism sector, enabling it to move into higher value-added parts of the tourism value chain. While the World Economic Forum places Tunisia high (9th place internationally) on price competitiveness, these findings confirm that Tunisia's long-standing problem of focusing mainly on low-cost mass tourism, resulting in "a low-equilibrium trap where the product had to continue to undercut prices at other destinations" (Hazboun 2008, p. 30) still persists (World Economic Forum 2015).

Considering the important role of the tourism sector in providing employment in a country struggling with high youth unemployment and massive interregional disparities (Benner 2014a; The World Bank 2011), it seems worthwhile to include tourism as a driving sector in cross-sectoral regional development strategies. Such strategies might include better valorization of existing natural or cultural assets in peripheral regions such as Le Kef, upgrading the attractiveness of old cities through urban renewal, developing niches of special-interest tourism along attractions such as the Tabarka Jazz Festival or the derelict but still existing sets of "Star Wars" movies in the South of the country, or linking tourism with other sectors in a smart specialization perspective. For example, Sousse/Monastir as one of the major destinations for sun/sand/beach package tourism and at the same time a major economic center with knowledge assets in information and communication technology could provide opportunities for developing e-tourism solutions. The region's modern Enfidha airport is another asset that could be further developed, for example by positioning it as an aviation hub between Europe, North Africa, and Sub-Saharan Africa, and by drawing on the region's existing potentials in engineering such as the science and technology park in Sousse. Such a cross-sectoral strategy would then offer development perspectives in the tourism, transport, aircraft maintenance, and engineering sectors. Yet another possibility to develop higher value-added tourism niches in Tunisian regions is linking tourism with signature products such as dates and olive oil-two sectors that are currently promoted through cluster policy and can serve as vehicles to promote tourism in peripheral regions in the South and North-West, respectively (Benner 2017b; Benner).

In such a context, the institution-sensitive kind of policy interventions to pursue according to the methodology of Glückler and Lenz (Glückler and Lenz 2016) prima facie consists in establishing institution-circumventing rules through instruments such as cluster policy or tourism improvement districts (Benner 2013; Benner et al. 2017). Such instruments could combine public and private efforts and establish patterns of common upgrading efforts, possibly shaping institutional patterns of cooperation and competition. Policy-induced cooperation in the framework of cluster organizations or tourism improvement districts could facilitate joint efforts in training staff in the tourism sector, in designing and implementing marketing campaigns to enter new markets or niches, and in combining public and private investments needed to upgrade a destination's attractiveness. 


\section{Agglomeration and Diffusion: Combining Divergent Goals in Integrated Tourism Development}

The preliminary ideas and stylized facts presented in the case studies in Section 4 demonstrate some ways of applying agglomeration-oriented approaches to tourism development in Mediterranean countries in a way that considers institutional particularities of the tourism sector in general and the examined tourist destinations in particular. In view of the apparent agglomeration of tourism in local destinations found all across the Mediterranean, promoting tourism development by seizing urbanization or localization economies seems worth pursuing, but doing so in an effective way requires institutional approach to policymaking.

However, higher-order goals or economic, social, and environmental policy such as environmental sustainability or socially or spatially inclusive growth may conflict with an agglomeration-focused approach to tourism development, implying some degree of tension between growth and equity-related goals of regional development in general and tourism development in particular. From an economic and social point of view, promoting the extension and diffusion of tourism-induced growth and employment effects to regions outside the main tourism agglomerations certainly is a valid policy objective. From an environmental point of view, tourism agglomerations may at some point be confronted with congestion effects and criticism among citizens about "too much" tourism-a phenomenon known from some of the major tourism agglomerations on the Spanish coast. A wider institutional perspective can be useful here, too, since it enables taking into account attitudes held by local populations towards (mass) tourism and social views on appropriate levels of tourism. In essence, political decisions to be taken in these cases (such as limiting the extension of tourism infrastructure or taxing mass tourism) will reflect a trade-off between economic impacts of (mass) tourism such as revenue and job creation and other social or ecological goals. ${ }^{7}$ Deciding on such a trade-off is intrinsically related to societal values and thus to the institutional context prevailing within a region or locality.

As the case studies presented in Section 4 suggest, the approaches laid out here do not necessarily preclude the diffusion of tourism away from already heavily touristed areas. Agglomeration and diffusion of tourism-induced growth and employment effects do not necessarily have to conflict. As the Tunisian case demonstrates, linking tourism development with wider cross-sectoral regional development strategies involving, for example, cluster promotion at cross-sectoral intersections can open up pathways for tourism development in new, higher value-added and more sustainable niches and in peripheral regions outside traditional tourism agglomerations. Where possible, drawing on urbanization economies even in smaller and more peripheral urban locations could be a further building block in designing a cross-sectoral, integrated agglomeration-diffusion strategy of tourism development.

In any case, agglomeration-oriented approaches to regional development should not be seen as a panacea for tourism development. Regional development offers a range of tools on how to promote sectors and localities and those targeting urbanization or localization economies are but one subset of tools to be applied if, when and where appropriate (Benner 2012a, pp. 19-22). Selecting the right kind of policy approach for each context is a delicate but highly important task, and it requires first and foremost institutional sensitivity. This article has attempted to apply an institution-sensitive perspective to tourism development and has suggested ways to adapt policies and rules to a region's or, more specifically, destination's institutional context. Further research can contribute to a refinement of institution-sensitive adaptations of policies building on agglomeration economies in the tourism sector. In particular, further detailed research on which policy levers are appropriate for which kind

7 Outside the Mediterranean perspective taken in this article, a case for debating such a trade-off would be Iceland with its spectacular growth in international tourist arrivals from 489,000 in 2010 to 1,289,000 in 2015 against the background of its small population size and sensitive ecosystem (World Tourism Organization 2016, p. 8). 
of institutional context may eventually provide policymakers in tourism development with tools to effectively promote their regional or local tourism industries in line with the institutional context of their economies and societies. Similar to the critical guiding question posed by Pike, Rodríguez-Pose and Tomaney (Pike et al. 2017), "what kind of local and regional development and for whom?", the thoughts presented here may lead to a research agenda that builds on the existing literature on tourism clusters, tourism policy, the role of institutions in regional development, and smart specialization, and that contributes further to answering the question "what kind of tourism development and for which institutional context?"

Conflicts of Interest: The authors declare no conflict of interest.

\section{References}

Asheim, Bjørn, Markus Grillitsch, and Michaela Trippl. 2016. Smart Specialization as an Innovation-Driven Strategy for Economic Diversification: Examples from Scandinavian Regions. Available online: http://wp.circle.lu.se/upload/CIRCLE/workingpapers/201623_asheim_et_al.pdf (accessed on 26 May 2016).

Assli, Abed. 2009. Northern Israel Tourism Improvement District: Executive Summary. Available online: http://milkeninnovationcenter.org/wp-content/uploads/2015/11/35-ENG-SUM.pdf (accessed on 11 January 2017).

Bathelt, Harald, and Johannes Glückler. 2012. Wirtschaftsgeographie: Ökonomische Beziehungen in Räumlicher Perspektive. (Economic Geography: Economic Relations in a Spatial Perspective), 3rd ed. Stuttgart: UTB.

Benner, Maximilian. 2012a. Clusterpolitik: Wege zur Verknüpfung von Theorie und Politischer Umsetzung. (Cluster Policy: Ways to Link Theory and Political Implementation). Münster: LIT.

Benner, Maximilian. 2012b. Cluster Policy: Principles and a Toolbox. Available online: http:/ /www.spaces-online. uni-hd.de/include/SPACES\%202012-01\%20Benner.pdf (accessed on 9 January 2017).

Benner, Maximilian. 2012c. What Do We Know About Clusters? In Search of Effective Cluster Policies. Available online: http://www.spaces-online.uni-hd.de/include/SPACES_2009-04_Benner.pdf (accessed on 26 May 2017).

Benner, Maximilian. 2013. Towards a policy to promote tourism clusters. MPRA Paper No. 43924. Munich Personal RePEc Archive. Available online: http://mpra.ub.uni-muenchen.de/43924/1/MPRA_paper_43924.pdf (accesses on 11 January 2017).

Benner, Maximilian. 2014a. Decentralised regional development policy in Tunisia: A new beginning after the “Arab Spring"? In International Reports. Vol. 6, Berlin: Konrad Adenauer Foundation, pp. 31-50. Available online: http:/ /www.kas.de/wf/doc/kas_38099-544-2-30.pdf?140618133239 (accessed on 28 February 2017).

Benner, Maximilian. 2014b. From smart specialisation to smart experimentation: Building a new theoretical framework for regional policy of the European Union. Zeitschrift für Wirtschaftsgeographie 58: 33-49. [CrossRef]

Benner, Maximilian. 2017a. Smart specialisation and cluster emergence: Building blocks for evolutionary regional policies. In The Life Cycle of Clusters: A Policy Perspective. Edited by R. Hassink and D. Fornahl. Camberley: Edward Elgar, pp. 151-72.

Benner, Maximilian. 2017b. The legacy of Sidi Bouzid: Overcoming spatial inequalities in Tunisia. In Beyond the 'Arab Spring' in North Africa: Macro and Micro Perspectives. Edited by D. Krížek and J. Záhorík. Lanham: Lexington, pp. 47-65.

Benner, Maximilian, Lukas Bieringer, Matthias Knaupp, Jana Wittemaier, and Adrian Wruck. 2016. Towards a Smart Specialization Strategy for Haifa. MPRA Paper No. 73299. Munich Personal RePEc Archive. Available online: https://mpra.ub.uni-muenchen.de/73299/1/MPRA_paper_73299.pdf (accessed on 10 January 2017).

Benner, Maximilian, Jana Hirth, Fabian Kraatz, Katja Ludwig, and Jessi Schrade. 2017. Regional development in the context of economic reform: The case of Limassol. MPRA Paper No. 76834. Munich Personal RePEc Archive. Available online: https:/ / mpra.ub.uni-muenchen.de/76834/1/MPRA_paper_76834.pdf (accessed on 20 February 2017). 
Benner, Maximilian. Forthcoming; Cluster policy in Tunisia: From institutional voids to smart specialization. In African Development Perspectives Yearbook 2018: Science, Technology and Innovation Policies for Inclusive Growth in Africa. Edited by T. Knedlik and K. Wohlmuth. In preparation.

Berg, Waldemar. 2010. Einführung Tourismus. (Introduction to tourism). In Grundlagen des Tourismus (Basics of Tourism). Edited by A. Schulz, W. Berg, M. A. Gardini, T. Kirstges and B. Eisenstein. Munich: Oldenbourg, pp. 1-138.

Bertan, Serkan, Ercan Sirakaya-Turk, and Volkan Altintaş. 2013. Tourism impacts and support for tourism development: The case of Pamukkale in Turkey. Tourismos 2: 97-115.

Dorfman, Nancy. 1983. Route 128: The development of a regional high technology economy. Research Policy 12 : 299-316. [CrossRef]

Enright, Michael. 2000. The globalization of competition and the localization of competitive advantage: Policies toward regional clustering. In The Globalization of Multinational Enterprise Activity and Economic Development. Edited by N. Hood and S. Young. London: Macmillan, pp. 303-31.

Enright, Michael. 2003. Regional clusters: What we know and what we should know. In Innovation Clusters and Interregional Competition. Edited by J. Bröcker, D. Dohse and R. Soltwedel. Berlin, Heidelberg, New York: Springer, pp. 99-129.

Foray, Dominique, Paul David, and Bronwyn Hall. 2009. Smart Specialisation-The Concept. Knowledge Economists Policy Brief No. 9. June. Available online: http:/ / ec.europa.eu/invest-in-research/pdf/download_en $/ \mathrm{kfg}$ policy_brief_no9.pdf (accessed on 10 January 2017).

Foray, Dominique, John Goddard, Xabier Goenaga Beldarrain, Mikel Landabaso, Philipp McCann, Kevin Morgan, Claire Nauwelaers, and Raquel Ortega-Argilés. 2012. Guide to Research and Innovation Strategies for Smart Specialisation (RIS 3). Luxembourg: Publications Office of the European Union.

Glückler, Johannes, and Regina Lenz. 2016. How institutions moderate the effectiveness of regional policy: A framework and research agenda. Investigaciones Regionales - Journal of Regional Research 36: 255-77.

Grabher, Gernot. 1993. The weakness of strong ties: The lock-in of regional development in the Ruhr area. In The Embedded Firm: On the Socioeconomics of Industrial Networks. Edited by G. Grabher. London, New York: Routledge, pp. 255-77.

Harvard Business School, ed. 2017. MOC Student Projects on Country E Cluster Competitiveness. Boston: Harvard Business School, Available online: http:/ / www.isc.hbs.edu/resources / courses / moc-course-at-harvard / pages/sample-student-projects.aspx (accessed on 24 May 2017).

Hazboun, Waleed. 2008. Beaches, Ruins, Resorts: The Politics of Tourism in the Arab World. Minneapolis: University of Minnesota Press.

Hjalager, Anne-Mette. 2000. Tourism destinations and the concept of industrial districts. Tourism and Hospitality Research 3: 199-213. [CrossRef]

Kachniewska, Magdalena. 2013. Towards the definition of a tourism cluster. Journal of Entrepreneurship, Management and Innovation 9: 33-56. Available online: https:/ / papers.ssrn.com/sol3/papers.cfm?abstract_ $\mathrm{id}=2410446$ (accessed on 26 May 2017).

Kassianidis, Panagiotis. 2013. Examining the image of a tourism destination: Evidence from Crete. Tourismos 2 : 259-70.

Kiehlmann, Fabian. 2014. Qualität im Cluster- und Netzwerkmanagement. (Quality in Cluster and Network Management). Wiesbaden: Springer.

Kiese, Matthias. 2008. Mind the Gap: Regionale Clusterpolitik im Spannungsfeld von Wissenschaft, Politik und Praxis aus der Perspektive der Neuen Politischen Ökonomie (Mind the Gap: Regional Cluster Policy between Academia, Politics, and Practice from a Perspective of New Political Economy). Zeitschrift für Wirtschaftsgeographie 52: 129-45.

Krugman, Paul. 1991. Geography and Trade. Leuven: Leuven University Press, Cambridge, London: MIT Press.

Lehmann, Tine, and Maximilian Benner. 2015. Cluster policy in the light of institutional context-A comparative study of transition countries. Administrative Sciences 5: 188-212. [CrossRef]

Martin, Ron, and Peter Sunley. 2003. Deconstructing Clusters: Chaotic Concept or Policy Panacea? Journal of Economic Geography 1: 5-35. [CrossRef]

Mavragani, Eleni, and Constantine Lymperopoulos. 2013. Factors affecting museum visitors' satisfaction: The case of Greek museums. Tourismos 2: 271-87. 
Ortega-Argilés, Raquel. 2012. Economic Transformation Strategies: Smart Specialisation Case Studies. Available online: http://s3platform.jrc.ec.europa.eu/documents/20182/141136/Econ_Transformation_ Strats_ROrtegaArgil\%C3\%A9s.pdf (accessed on 26 May 2017).

Partalidou, Maria, and Stavriani Koutsou. 2012. Locally and socially embedded tourism clusters in rural Greece. Tourismos 1: 99-116.

Pike, Andy, Andrés Rodríguez-Pose, and John Tomaney. 2017. Local and Regional Development, 2nd ed. Abingdon, New York: Routledge.

Piore, Michael, and Charles Sabel. 1984. The Second Industrial Divide: Possibilities for Prosperity. New York: Basic Books.

Porter, Michael. 1990. The Competitive Advantage of Nations. New York: Free Press.

Porter, Michael. 1998a. Clusters and competition: New agendas for companies, governments, and institutions. In On Competition. Edited by M. E. Porter. Boston: Harvard Business School Press, pp. 197-287.

Porter, Michael. 1998b. Clusters and the new economics of competition. Harvard Business Review 6: 77-92.

Porter, Michael. 2000. Location, competition, and economic development: Local clusters in a global economy. Economic Development Quarterly 1: 15-34. [CrossRef]

Saxenian, AnnaLee. 1994. Regional Advantage: Culture and competition in Silicon Valley and Route 128. Cambridge, London: Harvard University Press.

Schätzl, Ludwig. 1994. Wirtschaftsgeographie 3: Politik. (Economic Geography 3: Policy), 3rd ed. Paderborn, Munich, Vienna, Zurich: Schöningh.

Schätzl, Ludwig. 2000. Wirtschaftsgeographie 2: Empirie (Economic Geography 2: Empirics), 3rd ed. Paderborn, Munich, Vienna, Zurich: Schöningh.

Schätzl, Ludwig. 2003. Wirtschaftsgeographie 1: Theorie. (Economic Geography 1: Theory), 9th ed. Paderborn, Munich, Vienna, Zurich: Schöningh.

Scott, Allen. 1988a. Flexible production systems and regional development: The rise of new industrial spaces in North America and Western Europe. International Journal of Urban and Regional Research 12: 171-86. [CrossRef]

Scott, Allen. 1988b. New Industrial Spaces: Flexible Production Organization and Regional Economic Development in North America and Western Europe. London: Pion.

Segarra-Oña, María-de-Val, Lluís Gaspar Miret-Pastor, Angel Peiro-Signes, and Rohit Verma. 2012. The effects of localization on economic performance: Analysis of Spanish tourism clusters. European Planning Studies 20: 1319-1334. Available online: http://scholarship.sha.cornell.edu/cgi/viewcontent.cgi?article=1501\& context=articles (accessed on 24 May 2017).

Steenbruggen, John. 2016. Tourism geography: Emerging trends and initiatives to support tourism in Morocco. Journal of Tourism $\mathcal{E}$ Hospitality 3: 224-39.

Steinecke, Albrecht. 2011. Tourismus. (Tourism), 2nd ed. Braunschweig: Westermann.

Storper, Michael, and Richard Walker. 1989. The Capitalist Imperative: Territory, Technology, and Industrial Growth. New York, Oxford: Basil Blackwell.

The World Bank, ed. 2011. Poor Places, Thriving People: How the Middle East and North Africa Can Rise Above Spatial Disparities. Washington: The International Bank for Reconstruction and Development, Available online: https: / openknowledge.worldbank.org/bitstream/handle/10986/2255/ 589970PUB0ID181UBLIC109780821383216.pdf (accessed on 28 February 2017).

TripAdvisor, L.L.C., ed. 2016. Certificate of Excellence. Needham: TripAdvisor LLC. Available online: https://www.tripadvisor.com/TripAdvisorInsights/CertificateOfExcellence\#tab $=0 \quad$ (accessed on 27 February 2017).

Wolfe, David, and Meric Gertler. 2004. Clusters from the inside and out: Local dynamics and global linkages. Urban Studies 41: 1071-93. [CrossRef]

World Economic Forum, ed. 2015. The Travel \& Tourism Competitiveness Report 2017: Paving the Way for a More Sustainable and Inclusive Future. Geneva: World Economic Forum, Available online: http:/ / www3.weforum. org/docs/WEF_TTCR_2017_web_0401.pdf (accessed on 26 May 2017). 
World Tourism Organization, ed. 2016. UNTWO Tourism Highlights 2016 Edition. Madrid: World Tourism Organization, Available online: http:/ / www.e-unwto.org/doi/pdf/10.18111/9789284418145 (accessed on 8 June 2017).

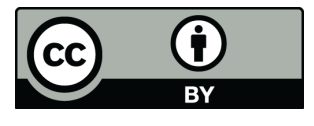

(C) 2017 by the author. Licensee MDPI, Basel, Switzerland. This article is an open access article distributed under the terms and conditions of the Creative Commons Attribution (CC BY) license (http://creativecommons.org/licenses/by/4.0/). 